\title{
Screen time characteristics and early-term parental concerns of children newly diag- nosed with autism spectrum disorder
}

\author{
ilk defa otizm spektrum bozukluğu tanısı alan çocuklarda ekran kullanım \\ özellikleri ve ebeveynlerin erken dönem endişeleri
}

Murat Eyüboğlu1, Damla Eyüboğlu1

${ }^{1}$ Assoc. Prof., Eskisehir Osmangazi Unversity Faculty of Medicine Department of Child and Adolescent Psychiatry, Turkey https://orcid.org/0000-0003-3278-0374-https://orcid.org/0000-0001-6042-7768

\section{SUMMARY}

Objective: Aim of this study was to explore the screen characteristics of children who have been newly diagnosed with Autism Spectrum Disorder (ASD) and context of initial concerns of parents at the time of the first diagnosis. Method: Fifty-seven ASD and 63 typically developing children were included. Data retrieved from families such as concerns at the time of referal and characteristics that comprised use of electronics were recorded. The Childhood Autism Rating Scale and Autism Behavior Checklist was administered by the clinician to evaluate the symptom severity of ASD. Furthermore, the Ankara Development and Screening Inventory were applied to the children to evaluate the general developmental level. Results: ASD was generally diagnosed around 36th month and parents of these children were found to have suspected of something going wrong regarding developmental characteristics of their children approximately 14 months prior formal diagnosis. Age at index use of electronics was smaller and screen time was higher in children with ASD. It has also been found that families most frequently were referred to the clinician due to problems in communication. Discussion: Our findings suggest children with ASD might be more prone to problematic use of electronics. Smaller index age for initiating use of electronic devices might predominantly affect socioemotional processes negatively. The clinicians should evaluate screen characteristics in these children. Lastly, It is important to encourage parents to report concerns to clinicians for early detection of ASD.

Key Words: ASD, screen, early indicators, first concerns, early identification
ÖZET

Amaç: Bu çalışmanın amacı, ilk defa Otizm Spektrum Bozukluğu (OSB) tanısı alan çocukların ekran kullanım özelliklerini ve ebeveynlerin bu çocuklarıyla ilgili ilk endişelerinin zamanı ve içeriğini araştırmaktır. Yöntem: Çalışmaya 57 OSB'li çocuk ve 63 sağlıklı gelişim gösteren çocuk alındı. Ebeveynlerin başvuru sırasındaki endişeleri ve çocukların elektronik alet kullanımı ile ilgili bilgiler ailelerden alındı. Çocukluk Otizmi Derecelendirme Ölçeği ve Otizm Davranış Kontrol Listesi klinisyen tarafından otizm belirtilerini değerlendirmek için uygulandı. Ayrıca çocukların genel gelişim düzeylerini saptamak amacıyla Ankara Gelişim ve Tarama Envanteri uygulandı. Bulgular: OSB genellikle 36. ayda teşhis edildi ve bu çocukların ebeveynlerinin resmi tanı konmadan 14 ay önce çocuklarının gelişimsel özellikleri ile ilgili yolunda gitmeyen bir şey olduğundan şüphe ettiği belirlendi. OSB'li çocukların elektronik alet kullanım yaşı daha küçük ve ekran kullanım süresi de daha yüksekti. Ayrıca en sık iletişim sorunları nedeniyle ailelerin klinisyene yönlendirildiği saptandı. Sonuç: Bulgularımız OSB'li çocukların sorunlu elektronik kullanımına daha yatkın olabileceğini göstermektedir. Elektronik aletlerin daha erken yaşta kullanılmaya başlanması sosyo-duygusal süreçleri olumsuz etkileyebilir. Klinisyenler bu çocuklarda ekran kullanımı özelliklerini değerlendirmelidirler. Son olarak, ebeveynlerin OSB'nin erken tanınması için endişelerini klinisyenlere bildirmeleri konusunda teşvik edilmesi oldukça önemlidir.

Anahtar Sözcükler: OSB, ekran, erken bulgular, ilk endişeler; erken tanıma

(Turkish J Clinical Psychiatry 2020;23:392-401)

DOI:10.5505/kpd.2020.23245 


\section{INTRODUCTION}

Autism spectrum disorder (ASD) is a neurodevelopmental disorder that occurs in the early developmental period of life and characterized by deficits in social communication and interaction, along with limited, repetitive behavior or interests (1). The disorder predominantly presenting in male gender by four times (2) and affecting one in every 59 children (3). It is now largely believed that ASD manifests itself based on coexisting genetic and environmental factors of vulnerability.

Nowadays, screen based electronic devices have progressively become an integral part in the daily life and age at onset of screen use tends to decrease gradually. Therefore, children and adolescents spend considerable amounts of their time, using electronic devices, social media, and playing video games. In this context, interest in the electronic use of children diagnosed with ASD has also increased. Even electronics devices may be useful in learning context, excessice exposure to screen may have adverse effect on children (4). Direct exposure to screen impact development of behavior (5), language (6), cognition (7) and attention (8) in children. These influences could be severe in children with ASD who have already difficulties in communication and social process (1).

Many children diagnosed with ASD spend significant amounts of their time in activities related to the video games and that involve screen use $(9,10)$. Parents have also indicated that these children have prolonged screen use, which also includes playing games, compared to time spent for other leisure time activities (10). Parents of boys with ASD reported that their sons spent more time playing video games per day (on average $2.1 \mathrm{~h} /$ day) than typically developing boys (on average $1.2 \mathrm{~h} /$ day) did (11). Individuals with ASD may be particularly prone to problematic electronic use, and studies have also shown that problematic electronic use is associated with social, behavioral, and academic challenges (12). In additon, higher screen time may results diminished parent-child interaction which is very important for cognitive and language development in the early period of life. Hermawati et al. showed that more than half of children $(66.6 \%)$ had no parents-child interaction during the screen exposure. Increased screen usage has also possible impact on spending less time in dailiy activities which may better advance in emotional-behavioral areas for children with ASD (13). Moreover, parents of children who have emotional and behavioral difficulties may use screen device as a calming tool when their children are upset (14). This may be one of the maintaining factor for difficulties with emotional/behavioral regulation in children with ASD who have already prone to develop behavioral-emotional problems (14). Therefore, it is important to know the nature and effect of using electronic devices in children with ASD, in order to develop intervention strategies towards relevant emerging behavioral and emotional problems.

Our current knowledge shows that the most effective treatment of this disorder is the behavior-based intervention programs $(15,16)$. Therefore, early detection of autism is crucial to provide early intervention. Increasing knowledge and awareness of parents, teachers, and physicans on autism in recent years, and the well- known notion that early treatment bearing better outcome might have contributed to the increase in early diagnosis of autism (17). However, the age at diagnosis has not decreased uniformly for all children, and the studies have shown that sex, ethnicity, access to health care, and symptom severity were factors found to be associated with age at diagnosis $(18,19)$. Although early diagnosis has not been maintained for most cases, parents might suspect possible developmental differences of their children throughout infancy and early childhood. It has been shown that $76.2 \%$ of parents were concerned about their children's developmental process, before the age of 3 (20). De Giacorno and Fombonne reported that mean age of children with ASD, when their parents first had suspicions regarding their children's development was 19 months, and mean age of the child when they sought help for the first time was 24 months (21). In another study, it was reported that mean age of children when parents had their initial concerns was 1.5 years for children diagnosed with Asperger Disorder, and help was sought approximately at the age of 3.5 years, and the children were diagnosed at 11 years (22). Findings indicate that parents report 
significantly earlier and more concerns about their child's, compared to parents of children with other developmental disabilities (23-25). In addition to these, it would also be important to identify what types of early-on concerns were the most common ones among parents of children with ASD. Howlin and Moore showed, majority of parents stated that their first concerns were about language delay, followed by social abnormalities, and behavioral problems (26).

In summary, previous findings have provided the importance of early detection and problematic electronics using in children with ASD. In the present study, we aimed to explore screen use characteristics, age at diagnosis, time and type of initial parental concerns of children with ASD, and to compare these variables with those of typically developing peers. Based on previous research, we hypothesized that individuals with ASD would begin using electronics at an earlier age, have prolonged times of electronics use. We have also hypothesized that parents of these children would be more likely to report negatively impacts of electronic use on their children's life, compared to parents of typically developing children.

\section{METHOD}

\section{Participants and Procedure}

A total of 57 children with ASD (47 boys, 10 girls) who were diagnosed for the first time and 63 typically developing (TD) were included in this crosssectional study between January 2020 and March 2020. Children with ASD were selected from pediatric psychiatry outpatient clinic and diagnosed by an experienced child and adolescent psychiatrist, based on DSM 5 diagnostic criteria, and diagnostic confirmation was made by another child psychiatrist, who was experienced in the relevant field. The typically developing children were selected from pediatric outpatient unit who had no history of physical or developmental disabilities. In determining process, one family rejected to participate to the study owing to child's agitation during the interview.

Written consents were obtained from all families who had agreed to participate in the study. The information obtained from families such as parental concerns and screen use characteristics were recorded to the checklist by physcian during the interwiev. Parents were asked to report the screen characteristics of children for the last month. Questions about screen characteristics and early concerns were asked by physican to the parents according and recorded. In the form, frequency of screen using were coded as "less than one hour", "1-2 hour", "2-4 hour" and "more than 4 hours" a day. Parents were also asked about the initial time for using electronics and whether the usage of screen affected their children. According to the answers related to affected areas, we classified the answers into the following groups: communication, social/emotional, behavioral problems and hyperactivity. Childhood Autism Rating Scale (CARS) and Autism Behavior Checklist (ABC) were administered by the clinician, to evaluate autism-related symptom severity of children with ASD. Furthermore, Ankara Development and Screening Inventory (ADSI) was applied to all children, in order to determine their development levels. Ethical approval was granted by the local ethics committee of the Eskisehir Osmangazi University (date: 07/01/2020, number:2019-417).

\section{Measures}

Childhood Autism Rating Scale (CARS): CARS is a scale consisting of 15 items that was developed to rate autism severity (27). The scale is mainly used in the assessment of children with autism and in differentiating the disorder from other developmental disorders. Turkish validity and reliability studies of the scale have been performed, and cutoff score was found to be 30 in (28).

Autism Behavior Checklist (ABC): $\mathrm{ABC}$ is a scale consisting of 57 items that describe symptoms associated with autism as well as more general behavior problems often seen in children with autism (29). Scores of the scale range from 0 to 159 points (the higher the score, the more severe symptoms). The Turkish validity and reliability of scale was performed (30).

Ankara Developmental Screening Inventory (ADSI): 
It is an inventory that evaluates development and skills of preschool children, in line with the information obtained from the caregiver. In this inventory of 154 items, questions are answered as "yes/no/do not know". Five different scores including the total development score and the languagecognitive, fine motor, gross motor and social skillself care scores representing different areas of development are obtained, as a result of the application (31).

\section{Data analyses}

Data were analyzed using Statistical Package for Social Sciences (SPSS) for Windows version 23.0. The continous variables were presented as mean \pm standard deviation, and categorical variables were presented as percentage and numbers. Kolmogorov-Smirnov test was used to evaluate distribution of numeric variables. According to the distribution of variables, Student's t test or MannWhitney $\mathrm{U}$ test were conducted in order to examine group differences (ASD vs. TD). Chi-square analyses and Fisher's exact tests were performed for dichotomous variables. Bivariate analyses were applied to assess level of relationship between numeric variables.The value of statistical signifi- cance was determined as $\mathrm{p}<.05$.

\section{RESULTS}

The mean age of ASD and TD children were found to be $35.5 \pm 10$ months and $36 \pm 9$ months, respectively. Groups did not differ by age $(p>0.05)$. The number of boys in the ASD group was higher compared to the TD group (Table 1). There were no significant differences between the two groups by the number of siblings, parental ages, father and mother's ages at pregnancy, and family income (Table 1). When parental education levels were examined, no difference was found regarding education level of fathers, while significant difference regarding education level of mothers was observed. There was also no significant differences in family income. Demographic variables were presented in Table 1.

In ASD group, 5 (8.7\%) children were diagnosed with epilepsy upon being evaluated by a child neurologist. Fifty-five $(96.5 \%)$ children with ASD had a history of language delay. According to the results of ADSI applied to children with ASD, the mean general development and social skill levels

Table 1. Demographic variables

\begin{tabular}{|c|c|c|c|c|c|}
\hline & & $\begin{array}{c}\text { ASD } \\
(\mathrm{n}=57)\end{array}$ & $\begin{array}{c}\mathrm{TD} \\
(\mathrm{n}=63)\end{array}$ & $\mathrm{p}$ & $\mathrm{Z} / \mathrm{t} / \mathrm{x}^{2}$ \\
\hline $\begin{array}{l}\text { Age } \\
\text { month,median(min-max) }\end{array}$ & & $36.0(20-66)$ & $36.0(21-55)$ & $0.595^{*}$ & -0.53 \\
\hline $\begin{array}{l}\text { Age of parental first concern } \\
\text { month,mean(SD) }\end{array}$ & & $21.5(8.4)$ & & & \\
\hline $\begin{array}{l}\text { Maternal age at pregnancy } \\
\text { year,mean(SD) }\end{array}$ & & 26.4 (5.6) & $27.3(3.9)$ & $0.268 * *$ & -1.43 \\
\hline $\begin{array}{l}\text { Paternal age at pregnancy } \\
\text { year, median(min-max) }\end{array}$ & & $26.0(19-36)$ & $26.0(20-33)$ & $0.32 *$ & -1.03 \\
\hline \multirow{2}{*}{$\begin{array}{l}\text { Gender } \\
\mathrm{n}(\%)\end{array}$} & boys & $47(82.5 \%)$ & $34(54 \%)$ & $0.001 * * *$ & 11.07 \\
\hline & girls & $10(17.5 \%)$ & $29(46 \%)$ & & \\
\hline $\begin{array}{l}\text { Number of siblings } \\
\text { median(min-max) }\end{array}$ & & $2.0(1-7)$ & $3.0-(1-7)$ & $0.137 *$ & -1.49 \\
\hline \multirow{4}{*}{$\begin{array}{l}\text { Mothers education } \\
\mathrm{n}(\%)\end{array}$} & Illiterate & $6(10.5 \%)$ & $4(6.3 \%)$ & $0.032 * * *$ & 8.80 \\
\hline & $\begin{array}{l}\text { Primary } \\
\text { education }\end{array}$ & $31(54.4 \%)$ & $20(31.7 \%)$ & & \\
\hline & High school & $9(15.8 \%)$ & $20(31.7 \%)$ & & \\
\hline & University & $11(19.3 \%)$ & $19(30.2 \%)$ & & \\
\hline \multirow{4}{*}{$\begin{array}{l}\text { Fathers education } \\
\mathrm{n}(\%)\end{array}$} & Illiterate & $2(4.2 \%)$ & $0(0 \%)$ & $0.579 * * *$ & 2.71 \\
\hline & $\begin{array}{l}\text { Primary } \\
\text { education }\end{array}$ & $22(38.6 \%)$ & $24(38.1 \%)$ & & \\
\hline & High school & $17(29.8 \%)$ & $16(25.4 \%)$ & & \\
\hline & University & $18(31.6 \%)$ & $23(36.5 \%)$ & & \\
\hline $\begin{array}{l}\text { Family income } \\
\text { TL,median(min-max) }\end{array}$ & & $2000(500-10000)$ & $\begin{array}{l}2500(500- \\
10000)\end{array}$ & $0.261 *$ & -1.12 \\
\hline
\end{tabular}


were $22.5 \pm 6$ months and $20 \pm 7$ months, respectively. All children with ASD also had comorbid developmental delay. Mean CARS score of children with ASD was $40 \pm 3.5$. According to the scoring standards of CARS, $11(19 \%)$ children had mild to moderate autism (CARS score between 30-36.5) and $46(81 \%)$ exhibited severe autism (CARS score above 37). The mean score of $\mathrm{ABC}$ was found to be $87 \pm 26$. Additionally, there were $8(14 \%)$ children diagnosed with ASD among the 1st and 2nd degree relatives of the children with ASD. Only one of the children in TD group had an individual diagnosed with ASD, among their close relatives.

\section{Use of electronics and screen time}

We examined daily screen (such as TV, phone, tablet, computer) use characteristics of all participating children within last month. Children with ASD had longer screen time per day, and had started to use electronics at an earlier age, compared to TD children (Table 3). Furthermore, majority of the families in ASD group stated that using electronics affected their children negatively, especially in the social/emotional context, along with domains that involve communication, behavioral problems and motor activity (Table 2).

Age of the child and type of initial parental concerns

Table 2. Screen Use Characteristics of Children
Mean age of children when the parents initial concerns were apparent was determined to be $21.5 \pm 8$ months. The age of ASD children in study entry was 35.5 months, so there was a period of approximately 14 months between the emergence of first concerns and being diagnosed with ASD. Most common reasons for referral to the clinician were symptoms related to communication and social/emotional domains. Features of parental concerns were presented in Table 3.

\section{Bivariate Analyses}

We used bivariate analyses to examine the relationship between autism severity, daily screen time, age at diagnosis and age of the child at the time of first parental concerns. While autism severity was significantly negative correlated with age at the time of first concerns, contrary to our hypothesis, no significant correlation was found between daily screen time and age at diagnosis (Table 4). Additionally, we found significant positive correlation between developmental delay and age at diagnosis in children with ASD. Table 4 presented relevant statistics of aforementioned correlations.

\section{DISCUSSION}

The present study examined characteristics of elec-

\begin{tabular}{|c|c|c|c|c|c|}
\hline & & $\begin{array}{l}\text { ASD } \\
(n=57)\end{array}$ & $\begin{array}{l}\text { TD } \\
(n=63)\end{array}$ & $\mathrm{p}$ & $\mathrm{Z} / \mathrm{x}^{2}$ \\
\hline \multirow{4}{*}{$\begin{array}{l}\text { Daily screen time } \\
\text { n }(\%)\end{array}$} & $<1$ hour & $5(8.8 \%)$ & $20(31.7 \%)$ & \multirow[t]{4}{*}{$<0.001 *$} & 39.93 \\
\hline & $1-2$ hours & $14(24.6 \%)$ & $34(54 \%)$ & & \\
\hline & 2-4 hours & $14(24.6 \%)$ & $8(12.7 \%)$ & & \\
\hline & $>4$ hours & $24(42.1 \%)$ & $1(1.6 \%)$ & & \\
\hline $\begin{array}{l}\text { Age at onset of } \\
\text { electronics use } \\
\text { month, median(min- } \\
\max \text { ) }\end{array}$ & & $12.0(2-24)$ & $18.0(12-36)$ & $<0.001^{* * *}$ & -7.07 \\
\hline \multirow{2}{*}{$\begin{array}{l}\text { Negative impact of } \\
\text { using electronics on } \\
\text { children daily life } \\
\mathrm{n}(\%)\end{array}$} & yes & $43(75.4 \%)$ & $36(57.1 \%)$ & \multirow[t]{2}{*}{$0.053^{*}$} & 4.45 \\
\hline & no & $14(24.6 \%)$ & $27(42.9 \%)$ & & \\
\hline \multirow{5}{*}{$\begin{array}{l}\text { Behavioral areas that } \\
\text { were reported to have } \\
\text { been affected by } \\
\text { screentime } \\
\text { n }(\%)\end{array}$} & Communication & $10(23.3 \%)$ & $2(5.6 \%)$ & $<0.001 *$ & 40.10 \\
\hline & Social/emotional & $19(44.2 \%)$ & $2(5.6 \%)$ & & \\
\hline & Behavioral problems & $11(25.5 \%)$ & $11(30.5 \%)$ & & \\
\hline & Hyperactivity & $2(4.7 \%)$ & $6(16.6 \%)$ & & \\
\hline & Other & $1(2.3 \%)$ & $15(41.7 \%)$ & & \\
\hline
\end{tabular}

*Chi-square test; ** Mann Whitney U test 
Table 3. Description of parental concerns

\begin{tabular}{llll}
\hline Category & & First concern & $\begin{array}{l}\text { Referral to } \\
\text { clinician }\end{array}$ \\
\hline Communication & Speech delay, receptive/expressive language problems & $\mathrm{n}(\%)$ & $\mathrm{n}(\%)$ \\
\hline Social/Emotional & Emotional response, interests, peer relationships & $17(29.8 \%)$ & $21(36.8 \%)$ \\
\hline $\begin{array}{l}\text { Communication }+ \\
\text { Social/Emotional }\end{array}$ & Speech delay, receptive/expressive language problems + & $9(15.8 \%)$ & $19(33.3 \%)$ \\
\hline Cognitive & Emotional response, interests, peer relationships & & $126.3 \%)$ \\
\hline Motor & Concerns about cognitive abilities, developmental delay & $4(7 \%)$ & - \\
\hline Hyperactivity & Walking, gross motor skills & $4(7 \%)$ & $1(1.8 \%)$ \\
\hline
\end{tabular}

tronics use, age and type of parental first concerns of children, that had newly been diagnosed with ASD, and their differences when compared with typically developing children. To summarize, we have found that children with ASD had prolonged screen time and were inclined to start using electronics at an earlier age compared to their healthy counterparts. We have also found that mean age of children with ASD at the time of diagnosis was 35.5 months, parents were concerned about their children's development approximately 14 months before their children would be diagnosed. Developmental delay was also a reason that motivated families of children with ASD to seek help from a medical professional.

Recently, growing concern about effect of prolonged electronics use on both children with ASD and TD has emerged. In our study, we found that children with ASD were exposed to electronic devices at an earlier age, and had longer daily screen time compared to typically developing peers. About $40 \%$ of the children with ASD had a total screen time for approximately 4 hours and above per day. This usage of screen exceeded the American Academy of Pediatrics' (AAP) recommendation (32) for screen use in children. In a study conducted with 91 ASD adolescents, average time of daily computer use was 4.9 hours (33). In another study, parents of typically developing children reported that their children spent approximately 1.2 hours on playing video games, per day (11). Additionally, it was stated that children with ASD spent less time in social media or interactive social games, and prefered to play computer games and watch television (34). It is not surprising that children with ASD are expected to have more nonsocial use of electronic by staying away from faceto-face interaction, compatible with the core symptoms of ASD. Furthermore, use of electronics among children with ASD, might be a way to provide a break for their caregivers. It is a well known fact that children with ASD have higher odds of hyperactive, impulsive and dysregulated behavior (35), and use of electronic devices and screen time might be a less consuming and easier way of controlling children for their caregivers. Moreover, the present study may indicates that parents at the times use electronics devices want to have free time, or take care of needs of their family. In documenting children's screen characteristics familylevel variables are also important. We found the lower levels of maternal education in children with ASD. This may be one of the factor that direct these children to use electronics devices.

Table 4. Bivariate correlations between study variables in children with ASD

\begin{tabular}{llllll}
\hline & $\begin{array}{l}\text { Age at } \\
\text { diagnosis }\end{array}$ & $\begin{array}{l}\text { Age at initial } \\
\text { concerns of } \\
\text { parents }\end{array}$ & $\begin{array}{l}\text { Daily screen } \\
\text { time }\end{array}$ & $\begin{array}{l}\text { General } \\
\text { developmental } \\
\text { level }\end{array}$ & CARS \\
\hline Age at diagnosis & 1 & & & & \\
\hline $\begin{array}{l}\text { Age at the time of } \\
\text { first parental } \\
\text { concerns }\end{array}$ & $0.56^{* *}$ & 1 & & \\
\hline Daily screen time & -0.07 & & 1 & 1 & \\
\hline $\begin{array}{l}\text { General } \\
\text { developmental level }\end{array}$ & $0.77^{* *}$ & -0.06 & -0.05 & & \\
(months) & & & & 1 \\
\hline CARS & -0.16 & $-0.36^{* *}$ & $0.34^{*}$ & $-0.56^{* *}$ & $0.54^{* *}$ \\
ABC & 0.23 & -0.16 & $0.36^{* *}$ & -0.73 & 1 \\
\hline
\end{tabular}

$* * \mathrm{p}<.01 ; * \mathrm{p}<.05$, CARS; Childhood Autism Rating Scale, ABC; Autism Behavior Checklist 
Competible with our finding it was shown that living with parents who have less education was associated with more screen time in ASD children (36). Another important aspect of the present study is possible difficulties in parent-child interaction in the early period of life. Due to the nature of disorder, parents may are unsure of how to connect with their infants and toddler, therefore they may let their children to use screen as a copy mechanism. In our study, children with ASD mostly use electronics devices alone. This is also diminished the quality of relationship with ASD children and decrease the duraion of caregiver-child reciprocal interaction. Therefore, it should be kept in mind that the negative impact of screen use, especially in children with ASD might be overlooked by their families. Our findings suggest that children with ASD might be more prone to problematic electronics use, because of their individual characteristics and nature of disorder. Because, as we know restricted interests and repetitive behaviors may increase the risk for problematic screen usage. Additionally, deficits in impulse control and response inhibition in ASD (37), might contribute to the predisposition these children for developing problematic electronics use. All aside, probably the most important point is overly- prolonged screen time exposure might further impair these childrens' interaction within social contexts and experiences with their peers. In line with the aforementioned statement, parents in our study have also reported use of electronics had the most negative impact on socio-emotional areas. Problematic internet and video game use have also shown to be associated with inattention and impulsivity (38). In one study, a relationship was reported between online gaming and oppositional behavior, among children with ASD (11). In general, evidence suggest that problematic electronics use is associated with social, behavioral, and academic difficulties (12). This would mean that the risk has increased a little more for those who were already prone to develop behavioral and emotional problems, due to the nature of the disorder. Moreover, excessive use of electronics might also affect families who would be already under stress because of the challenging nature of the disorder, much more negatively. Therefore, families and clinicians need to be aware of their children's use of electronics and inititate and employ required interventions, without allow- ing further clinical deterioration.

Early identification of ASD has become more important with increasing evidence that demonstrates positive outcomes of early behavioral interventions in afflicted children (39). Early recognition of atypical developmental features by parents has also been found to associate with early diagnosis of autism $(20,40)$. In our study, we found that mean age of the children at the time of first parental concerns about their children's development had emerged, was 21.5 months. In previous studies that explored the same context, discrepant results were found, such as 19, 15 and 14 months, respectively $(21,41,42)$. Increasing awareness of parents regarding their children's development, might possibly account for the earlier ages at when the disorder would be suspected of. The age of the children at the time of first parental concern in our study seems a little bit higher, compared to the results reported by previous studies. We think this difference might be associated with lower levels of maternal education in our ASD group. Such interpretation might have grounds, as supported by the study that reported increased awareness of mothers on children's development, as education level increased (43). Additionally, cultural differences may impact the perception of symptoms of ASD and parents' concerns may vary according to culture (44). Even there is no study investigating the cultural differences in Turkish population, this differences may be also a factor that caused a little elongation of the time for parental first concerns. Turkish parents may not sufficiently aware about the early developmental steps of their children and this finding emphasizes the important of increasing autism awareness once again.

It was reported that within the early developmental period, communication impairments and language delay were the most commonly reported initial parental concerns of children with ASD $(21,23,41)$. These aforementioned concerns were followed by impairments in social skills $(41,45)$. In the present study, initial concerns of parents to children with ASD were communication problems and social impairments; and they most frequently were referred to the clinician due to problems in communication, especially speech delay. Consistent with the results of previous studies, we have found 
that social impairments and related symptoms constituted the second area of parental concerns. Although early identification of ASD is encouraged, a significant time between age of children at first parental concerns and the age at diagnosis of ASD were consistently reported, via previous studies. Howlin and Asgharian reported that average age at initial parental concern was 18 months of age for autism, whereas the diagnostic confirmation of the disorder was prolonged to 66 months (22). In a population based study, it was shown that there was a delay of 20-60 months between initial parental suspicions and the time of clinical diagnosis (46). In another study, it was reported that there was a period of 13 months between the initial clinical assessment of the child and the time of formal diagnosis (19). In our study, the time between initial parental concerns and the time of ASD diagnosis, was 14 months. Positive history for language and developmental delay in all children with ASD from our sample might have affected the time in between and caused an earlier detection through referal. Supporting this finding, a significant relationship was also found between general developmental level and age at diagnosis, suggesting that comorbid developmental delay could have an impact on earlier referal or application to a medical professional.

\section{Limitations of the study}

Several limitations should be considered when interpreting our results. Although CARS and ABC were used to evaluate autism severity, no standardized diagnostic tool was used for the diagnosis of ASD. It should be noted that our study largely relied on parental reports for all measured. This is also increased the possibility of bias. Our small sample size would constitute one of the main limitations of the study and the cross-sectional design of the study also does not allow to generalize our results. Finally, the use of alternative measures of screen characteristics would be helpful. Additionally, studies investigated screen characteristics by gender differences in children with ASD showed that being male is associated with higher levels of screen time and may exhibited higher rates of problematic electronics use than girls (12). In our study, due to nature of the disorder there were more males in case group, and this may effect the our results related to high frequency of screen time in ASD children. Future researches is essential in order to inform the parents how to use of electronic devices properly to possible improvements on functional outcomes in children with ASD.

\section{CONCLUSION}

In conclusion, we have found that children with ASD were diagnosed when they were at approximately 36 months old, parental concerns about their children's developmental steps emerged 14 months prior to formal diagnosis, children with ASD had more electronics use than their healthy peers, even before they were formally diagnosed with the disorder, they had met electronic devices at an earlier age, and their parents reported electronics use had specifically had a negative impact on the social-emotional area. In addition, children with ASD may be at higher risk of exceeding the AAP total screen recommendation. It was considered that electronics use starting at such an early age posed a risk for children with ASD. Further studies are required for families and clinicians to develop strategies for coping with this problem. The results of the present study highlight the clinical importance of examining electronics using pattern and need for increased awareness of problematic electronics use for individuals with ASD. In addition, subsequent researches should also focus on identifying factors that affect age of children at the time first parental concerns emerged, and improved techniques and methods to adopt, for earlier detection of the disorder. Further experimental and longitudinal researches may help to improve our knowledge about etiology, early detection and effect of electronic in ASD.

Conflict of Interest: The authors declare that they have no conflict of interest

Correspondence address: Assoc. Prof. Murat Eyuboglu, Eskisehir Osmangazi Unversity Faculty of Medicine Department of Child And Adolescent Psychiatry, Turkey murateyuboglu@hotmail.com 


\section{REFERENCES}

1. American Psychological Association (APA). Diagnostic and Statistical Manual of Mental Disorders: DSM 5, Washington, DC: Author; 2013.

2. Loomes R, Hull L, Mandy WPL. What Is the Male-toFemale Ratio in Autism Spectrum Disorder? A Systematic Review and Meta-Analysis. J Am Acad Child Adolesc Psychiatry 2017;56:466-74.

3. Baio J, Wiggins L, Christensen DL, Maenner MJ, Daniels J, Warren Z, Kurzius-Spencer M, Zahorodny W, Robinson Rosenberg C, White T, Durkin MS, Imm P, Nikolaou L, YearginAllsopp M, Lee LC, Harrington R, Lopez M, Fitzgerald RT, Hewitt A, Pettygrove S, Constantino JN, Vehorn A, Shenouda J, Hall-Lande J, Van Naarden Braun K, Dowling NF. Prevalence of Autism Spectrum Disorder Among Children Aged 8 Years Autism and Developmental Disabilities Monitoring Network, 11 Sites, United States, 2014. MMWR Surveill Summ 2018:67;1-23.

4. Krupa M, Boominathan P, Ramanan PV, Sebastian S. Relationship between screen time and mother-child reciprocal interaction in typically developing children and children with autism spectrum disorders. Indian J Pediatr 2019:86:394.

5. Ozmert E, Toyran M, Yurdakök K. Behavioral correlates of television viewing in primary school children evaluated by the child behavior checklist. Arch Pediatr Adolesc Med 2002:156:910-914.

6. Chonchiaiya W, Pruksananonda C. Television viewing associates with delayed language development. Acta Paediatr 2008:97:977-982.

7. Zimmerman FJ, Christakis D.A. Children's television viewing and cognitive outcomes: a longitudinal analysis of national data. Arch Pediatr Adolesc Med 2005:159:619-25.

8. Christakis DA, Zimmerman FJ, DiGiuseppe DL, McCarty CA. Early television exposure and subsequent attentional problems in children. Pediatrics 2004:113:708-713.

9. Mineo BA, Ziegler W, Gill S, Salkin D. Engagement with electronic screen media among students with autism spectrum disorders. J Autism Dev Disord 2009:39;172-187.

10. Shane HC, Albert PD. Electronic screen media for persons with autism spectrum disorders: results of a survey. J Autism Dev Disord 2008:38;1499-1508.

11. Mazurek MO, Engelhardt CR. Video game use in boys with autism spectrum disorder, ADHD, or typical development. Pediatrics 2013:132;260-266

12. MacMullin JA, Lunsky Y, Weiss JA. Plugged in: Electronics use in youth and young adults with autism spectrum disorder. Autism 2016:20;45-54

13. Hermawati D, Rahmadi FA, Sumekar TA, Winarni TI. Early electronic screen exposure and autistic-like symptoms. Intractable Rare Dis Res 2018:7;69-71.

14. Radesky JS, Peacock-Chambers E, Zuckerman B, Silverstein M. Use of mobile technology to calm upset children: associations with social-emotional development. JAMA Pediatr 2016:170:397-399.

15. Matson JL, Mahan S, LoVullo SV. Parent training:A review of methods for children with developmental disabilities. Res
Dev Disabil 2009:30;961-968.

16. Linstead E, Dixon D, French R, Granpeesheh D, Adams H, German R, Powell A, Stevens E, Tarbox J, Kornack. Intensity and learning outcomes in the treatment of children with autism spectrum disorder. Behav Modif 2016:41;229-252.

17. Fountain C, King MD, Bearman PS. Age of diagnosis for autism: individual and community factors across 10 birth cohorts. J Epidemiol Community Health 2011;65:503-510

18. Shattuck PT, Durkin M, Maenner M, Newschaffer C, Mandell DS, Wiggins L, Lee LC, Rice C, Giarelli E, Kirby R, Baio J, Pinto-Martin J, Cuniff C. Timing of identification among children with an autism spectrum disorder: findings from a population-based surveillance study. J Am Acad Child Adolesc Psychiatry 2009;48(5):474-483

19. Wiggins LD, Baio J, Rice C. Examination of the time between first evaluation and first autism spectrum diagnosis in a population-based sample. J Dev Behav Pediatr 2006:27(2 Suppl);79-87

20. Kishore MT, Basu A. Early concerns of mothers of children later diagnosed with autism: Implications for early identification. Res Autism Spectr Disord 2011:5;157-163

21. De Giacomo A, Fombonne E. Parental recognition of developmental abnormalities in autism. Eur Child Adolesc Psychiatry 1998; 7;131-136.

22. Howlin P, Asgharian A. The diagnosis of autism and Asperger syndrome: findings from a survey of 770 families. Dev Med Child Neurol 1999:41); 834-839.

23. Kozlowski AM, Matson JL, Horovitz M, Worley JA, Neal D. Parents' first concerns of their child's development in toddlers with autism spectrum disorders. Dev Neurorehabil 2011:14;7278

24. Ozonoff S, Young GS, Steinfeld MB, Hill MM, Cook I, Hutman T, Macari S, Rogers SJ, Sigman M. How early do parent concerns predict later autism diagnosis?. J Dev Behav Pediatr 2009:30;367-375

25. Zuckerman KE, Lindly OJ, Sinche BK. Parental concerns, provider response, and timeliness of autism spectrum disorder diagnosis. J Pediatr 2015:166;1431-1439.

26. Howlin P, Moore A. Diagnosis in Autism:A Survey of Over 1200 Patients in the UK. Autism 1997:1;135-162.

27. Schopler E, Reichler RJ, Rochen Renner B. The Child hood Autism Rating Scale (CARS) (11th. ed.): Western Psychological Services, 2007.

28. Gassaloglu SI, Baykara B, Avcil S, Demiral Y. Validity and Reliability Analysis of Turkish Version of Childhood Autism Rating Scale. Turk Psikiyatri Derg 2016:27;266-274

29. Krug DA, Arick JR, Almond PJ. Autism behavior checklist. Austin, TX: PRO-ED, 1980

30. Irmak TY, Sutcu S, Aydın A, Sorias O. An investigation of validity and reliability of autism behavior checklist (ABC). Turkish Journal of Child and Adolescent Mental Health 2007:14: 13-23

31. Sezgin N, Erol N, Savasır I. 0-6 yaş çocukları için Gelişim 
Tarama Envanteri. Turk Psikiyatri Derg 1993:4; 9-17.

32. American Academy of Peaidtric Council on Communications and Media. (2016). Media and Young Minds. Pediatrics, 138(5):e20162591.

33. Kuo MH, Orsmond GI, Coster WJ, Cohn ES. Media use among adolescents with autism spectrum disorder. Autism 2014:18;914-923

34. Mazurek MO, Wenstrup C. Television, video game and social media use among children with ASD and typically developing siblings. J Autism Dev Disord 2013:43;1258-1271

35. Burt KB, Obradovic' J, Long JD, Masten AS. The interplay of social competence and psychopathology over 20 years: Testing transactional and cascade models. Child Dev 2008:79;359-374.

36. Anand D, Krosnick JA. Demographic predictors of media use among infants, toddlers and preschoolers. Am Behav Sci 2005;48:539-561

37. Corbett BA, Constantine LJ, Hendren R, Rocke D, Ozonoff $\mathrm{S}$. Examining executive functioning in children with autism spectrum disorder, attention deficit hyperactivity disorder and typical development. Psychiatry Res 2009:166;210-22.

38. Rehbein F, Kleimann M, Mossle T. Prevalence and risk factors of video game dependency in adolescence: results of a German nationwide survey. Cyberpsychol Behav Soc Netw 2010:13;269-277.

39. Zwaigenbaum L, Bauman ML, Choueiri R, Fein D, Kasari C, Pierce K, Stone WL, Yirmiya N, Estes A, Hansen RL, McPartland JC, Natowicz MR, Buie T, Carter A, Davis PA, Granpeesheh D, Mailloux Z, Newschaffer C, Robins D, Smith Roley S, Wagner S, Wetherby A. Early Identification and Interventions for Autism Spectrum Disorder: Executive Summary. Pediatrics 2015:136(Suppl)1;1-9

40. Zwaigenbaum L, Bauman ML, Choueiri R, Kasari C, Carter A, Granpeesheh D, Mailloux Z, Smith Roley S, Wagner S, Fein D, Pierce K, Buie T, Davis PA, Newschaffer C, Robins D, Wetherby A, Stone WL, Yirmiya N, Estes A, Hansen RL, McPartland JC, Natowicz MR. Early Intervention for Children With Autism Spectrum Disorder Under 3 Years of Age: Recommendations for Practice and Research. Pediatrics 2015:136(Suppl 1);60-81

41. Chawarska K, Paul R, Klin A, Hannigen S, Dichtel LE, Volkmar F. Parental recognition of developmental problems in toddlers with autism spectrum disorders. J Autism Dev Disord 2007:37:62-72

42. Matheis M, Matson JL, Burns C1, Jiang X, Peters WJ, Moore M, de Back KA, Estabillo J. Factors related to parental age of first concern in toddlers with autism spectrum disorder. Dev Neurorehabil 2017:20;228-235.

43. Reich S. What do mothers know? Maternal knowledge of child development. Infant Ment Health J 2005:26;143-156

44. Matson JL, Matheis M, Burns CO, Esposito G, Venuti P, Pisula E, Misiak A, Kalyva E, Tsakiris V, Kamio Y, Ishitobi M, Goldin RL. Examining cross-cultural differences in autism spectrum disorder: A multinational comparison from Greece, Italy, Japan, Poland, and the United States. Eur Psychiatry 2017:42;70-76
45. Hess CR, Landa RJ. Predictive and concurrent validity of parent concern about young children at risk for autism. J Autism Dev Disord 2012:42;575-584

46. Sivberg B. Parents' detection of early signs in their children having an autistic spectrum disorder. J Pediatr Nurs 2003:18;433-439. 